\title{
The Effectiveness of Green Bean Juice on Hemoglobin Levels in Teenagers
}

\author{
$1^{\text {st }}$ Piscolia Dynamurti Wintoro \\ Midwifery Department \\ Sekolah Tinggi Ilmu Kesehatan \\ Muhammadiyah Klaten \\ Klaten, Indonesia \\ dynamurtiwintoro91@gmail.com
}

\author{
$2^{\text {nd }}$ Wiwin Rohmawati \\ Midwifery Department \\ Sekolah Tinggi Ilmu Kesehatan \\ Muhammadiyah Klaten \\ Klaten, Indonesia
}

\author{
$3^{\text {rd }}$ Endang Wahyuningsih \\ Midwifery Department \\ Sekolah Tinggi Ilmu Kesehatan \\ Muhammadiyah Klaten \\ Klaten, Indonesia
}

\begin{abstract}
Teenager period is the most critical for development at a later stage in life. Many changes occur in individuals both physically and psychologically. Anemia is defined as a hemoglobin level of less than $12.0 \mathrm{gram} / 100 \mathrm{ml}$. In 2018 , the prevalence of anemia in Indonesia was $21.7 \%$ with anemia patients aged 5-14 years at $26.4 \%$ while anemia patients aged $15-24$ years was $18.4 \%$. The purpose of this study was to determine the effect of giving green bean juice on hemoglobin levels on the eighth grade students of Jogonalan 1 Junior High School. The research method used was quantitative, preexperimental designs (Non-designs) with pretest-posttest with control group. The population was all eighth grade students of Jogonalan 1 Junior High School, namely 138 students. The sample used in this study was 24 students consisting of 12 case groups and 12 control groups. The results showed that green bean juice was effective for increasing hemoglobin levels with a $p$ value of $0,000(p<0.05)$. The conclusion is green bean juice is effective for increasing hemoglobin levels. It is suggested that the school can work together with the canteen in providing green bean juice in order to prepare a generation that is not anemic.
\end{abstract}

\section{Keywords-Green Bean Juice, Hemoglobin, Teenagers}

\section{INTRODUCTION}

Teenager is the most difficult period for individuals. This is the most critical period for development towards the next stage of life. There are many changes inside the individuals, both physically and psychologically, as well as changes from the characters of childhood to adulthood [1]. Anemia in adolescent girls can result adverse effects on educational performance, productivity, and well-being. Preventing iron deficiency and increasing iron stores in adolescent girls can improve their iron status for preparing pregnancy and is beneficial for health and well-being during pregnancy [2]. Based on data of Basic Health Research (Riskesdas) 2018, the prevalence of anemia in Indonesia is $21.7 \%$, with the number of anemia patients aged 5-14 years of $26.4 \%$ and the number of anemia patients aged 15-24 years of $18.4 \%$. The prevalence of iron deficiency anemia in adolescents based on sex is $22.7 \%$ for females and $12.4 \%$ for males [3]. Meanwhile, in 2017, Department of Health of Klaten Regency stated that the incidence of anemia of adolescent girls aged 10-14 years was $65.3 \%$ and adolescent girls aged $15-18 \%$ was $52.4 \%$ [4]. The main benefit of green bean is as the source of nutrition. Green bean is a good and easily digestible source of vegetable protein, amino acids, calcium, and phosphorus, which is good for bones and contains much unsaturated fat. Green beans also help meet the needs of vitamin B1 or thiamine. This compound helps prevent beriberi and supports human growth. Vitamin B1 is also able to increase appetite and to improve the digestive tract. Green beans also contain vitamin B2 that helps the absorption of protein by the body [5]. Based on the preliminary studies conducted on November 19, 2018 at SMP $\mathrm{N} 1$ Jogonalan, the results of the examination of hemoglobin levels carried out to 12 female students show that 5 female students have hemoglobin levels of 8 gr\% or categorized as anemic, while 7 female students have hemoglobin levels of 11 gr\% or categorized as normal. Green bean extract is given to 5 students whose hemoglobin level of 8 gr\% for 7 days every morning. After giving green bean, it is seen that the hemoglobin of 4 students increases for 1-2 gr/dl, which becomes $9 \mathrm{gr} \%$ and $10 \mathrm{gr} \%$. Meanwhile, hemoglobin of 1 girl does not increase because she was having menstruation when checking the level of hemoglobin again. This research aims to find out the effects of giving green bean extract on the level of hemoglobin of the eighth grade of students in SPM N 1 Jogonalan.

\section{RESEARCH METHOD}

This study used quantitative research method with the PreExperimental Designs (Non-design) approach with PretestPosttest and control groups. The population in this study was all eighth grade students at SMP N 1 Jogonalan, namely 138 people. The samples in this study were 24 students who met the inclusion and exclusion criteria. The sampling technique in this study used non-probability sampling. The instruments used in this study were an observation sheet to assess the levels of hemoglobin, digital scales and pans to weigh and to process green beans into green bean extracts. Meanwhile, to measure hemoglobin levels using a calibrated digital hemometer. Bivariate analysis in this study used mann whitney. 
A. Result

\section{RESULT AND DISCUSSION}

TABLE I. DISTRIBUTION OF THE LEVEL OF HEMOGLOBIN BEFORE AND AFTER CONSUMING GREEN BEAN EXTRACT IN SMP N I JOGONALAN, KLATEN

\begin{tabular}{|l|l|l|l|l|}
\hline \multirow{2}{*}{$\begin{array}{c}\text { Level of } \\
\text { Hemoglobin }\end{array}$} & \multicolumn{3}{|c|}{ Intervention Group } \\
\cline { 2 - 5 } & \multicolumn{2}{|c|}{ Before } & \multicolumn{2}{c|}{ After } \\
\cline { 2 - 5 } & $\mathrm{F}$ & $\%$ & $\mathrm{~F}$ & $\%$ \\
\hline Normal & 0 & 0 & 10 & 83.3 \\
\hline Non-Normal & 12 & 100 & 2 & 16.7 \\
\hline Total & 12 & 100 & 12 & 100 \\
\hline
\end{tabular}

a. Source: Primary Data 2019 Level of Hemoglobin in control group of pretest and posttest

TABLE II. AVERAGE OF LEVEL OF HEMOGLOBIN IN CONTROL GROUP OF PRETEST AND POSTTEST OF THE RESPONDENTS IN SMP N I JOGONALAN, KLATEN

\begin{tabular}{|l|l|l|l|l|}
\hline \multirow{2}{*}{$\begin{array}{c}\text { Level of } \\
\text { Hemoglobin }\end{array}$} & \multicolumn{2}{|c|}{ Intervention Group } \\
\cline { 2 - 5 } & \multicolumn{2}{|c|}{ Before } & \multicolumn{2}{c|}{ After } \\
\cline { 2 - 5 } & $\mathrm{F}$ & $\%$ & $\mathrm{~F}$ & $\%$ \\
\hline Normal & 0 & 0 & 1 & 8.3 \\
\hline Non-Normal & 12 & 100 & 11 & 91.7 \\
\hline Total & 12 & 100 & 12 & 100 \\
\hline
\end{tabular}

In this study, normality test was carried out to examine differences in the pretest and posttest values of each group. Based on Shapiro Wilk Test, the results of normality test of $p$ value of the case group is $0.829>\alpha(0.05)$, while $p$ value of the control group is $0.014<\alpha(0.05)$. It can be concluded that the case group data is normally distributed and the control group is not normally distributed. Because there is one data that is not normally distributed, further statistical tests must use Mann Whitney test.

TABLE III. THE EFFECTS OF CONSUMING GREEN BEAN EXTRACT ON THE LEVEL OF HEMOGLOBIN IN SMP N 1

\begin{tabular}{|c|l|l|l|l|}
\hline \multicolumn{5}{|c|}{ JOGONALAN, KLATEN } \\
\hline & Group & N & $\begin{array}{c}\text { Mean } \\
\text { Rank }\end{array}$ & $\begin{array}{c}\text { P } \\
\text { value }\end{array}$ \\
\hline $\begin{array}{c}\text { Level of } \\
\text { Hemoglobin }\end{array}$ & Case & 12 & 17.79 & 0.000 \\
\cline { 2 - 5 } & Control & 12 & 7.21 & \\
\hline \multicolumn{4}{|l|}{ c. Source: Primary Data 2019}
\end{tabular}

Based on table III, it can be seen that $p$ value of Mann Whitney test is 0.000 , so $p$ value $<0.05$. It can be concluded that there are effects of consuming green bean on the level of hemoglobin.

\section{B. Discussion}

Based on table III, it can be seen that $p$ value of the Mann Whitney Test is 0,000 so that the $p$ value $<0.05$. It can be concluded that there is an effect of giving green bean extract on hemoglobin levels. The results of this study are in line with a research conducted by Zakaria and Fatma (2018). It is stated that hemoglobin level of adolescent girls before consuming green bean extract results in a mean value of 2.38 with a standard deviation of 0.492 and after consuming green bean extract results is a mean value of 1.38 with a standard deviation of 0.492 . The conclusion in this study is green bean extract increases hemoglobin levels in adolescent girls [6].

Green bean, besides containing iron, vitamin $\mathrm{C}$, and zinc that play a role in handling iron deficiency anemia, also contains $7 \mathrm{mcg}$ of vitamin $\mathrm{A}$ in half of a cup. Vitamin A deficiency can worsen iron deficiency anemia. Giving vitamin
A supplementation has a beneficial effect on iron deficiency anemia. Vitamin A has many roles in the body, including for the growth and differentiation of progenitor erythrocyte cells, body's immune against infection, and mobilization of iron reserves throughout the tissue. The interaction of vitamin A with iron is synergistic. One type of beans that contain high iron is green beans (phaseolus radiates $\mathrm{L}$ ), which is a source of vegetable protein, vitamins $(\mathrm{A}, \mathrm{B}, \mathrm{C}$, and $\mathrm{E})$ and several other substances that are very beneficial for the human body, such as amylium, iron, sulfur, calcium, fat oil, manganese, magnesium, and niacin. The highest iron content in green beans is in its embryo and seed peels, with the amount of iron content of $6.4 \mathrm{mg}$ per 100 grams of green beans [7].

Green bean is a good and easily digestible source of vegetable protein, amino acids, calcium, and phosphorus, which is good for bones and contains much unsaturated fats. Green bean also helps meet the needs of vitamin B1 or thiamine, and B2, which helps the body in absorbing protein. In addition, green bean in the form of sprouts contains 12 times more iron. Thus, consuming green bean, which is rich of iron, will be very good for a healthy diet [5].

\section{CONCLUSION}

Based on the explanation above, it can be concluded that green bean extract can significantly increase hemoglobin levels in the blood because it contains iron, vitamin $\mathrm{C}$, zinc, and vitamin $\mathrm{A}$ that has many roles in the body. Those nutritional contents are good for the growth and differentiation of progenitor erythrocyte cells, body immune against infection, and mobilization of iron reserves throughout the tissue. Thus, it is recommended for adolescents or female students to drink green bean extract during menstruation or after menstruation to prevent the occurrence of iron deficiency anemia.

\section{ACKNOWLEDGMENT}

The authors would like to thank Sekolah Tinggi Ilmu Kesehatan Muhammadiyah Klaten for supporting in the publication of this research References

\section{REFERENCES}

[1] A. Scull, A. T. Franzese, and K. Dodge, "A Reference for Professionals Developing Adolescents," Cult. Sociol. Ment. Illn. An A-to-Z Guid., 2014.

[2] H. M. Creed-Kanashiro et al., "Improving Dietary Intake to Prevent Anemia in Adolescent Girls through Community Kitchens in a Periurban Population of Lima, Peru," J. Nutr., vol. 130, no. 2, pp. 459S-461S, 2000.

[3] R. Kemenkes, "Hasil Utama Rikesdas," J. Phys. A Math. Theor., vol. 44 , no. 8, pp. 1-200, 2018.

[4] Dinas Kesehatan Kabupaten Klaten, "Profil kesehatan kabupaten klaten tahun 2017," no. 0272, pp. 1-195, 2018.

[5] R. Y. Yang and S. C. S. Tsou, "Mungbean as a Potential Iron Source in South Asian Diets," no. November, pp. 152-158, 2014.

[6] F. Zakaria, M. W. Aisya, and Y. Lamatowa, "Effectiveness of Green bean Drink on the Improvement of Hemoglobin in Female Adolescents in Paguyaman District," Saudi J. Biol. Sci., vol. 3, no. 3 , pp. $125-128,2018$.

[7] M. Astawan, Sehat Dengan Hidangan Kacang dan Biji-Bijian. Jakarta: Penebar Swadaya, 2009. 